University of Montana

ScholarWorks at University of Montana

Spring 2013

\title{
A Functional Analysis of 2012 U.S. Presidential Primary Debates
}

\author{
Mark Glantz \\ St. Norbert College \\ William L. Benoit \\ Ohio University, Athens, $\mathrm{OH}$, benoitw@ohio.edu \\ David Airne \\ University of Montana - Missoula, davidairne@gmail.com
}

Follow this and additional works at: https://scholarworks.umt.edu/communications_pubs

Part of the Communication Commons

Let us know how access to this document benefits you.

\section{Recommended Citation}

Glantz, Mark; Benoit, William L.; and Airne, David, "A Functional Analysis of 2012 U.S. Presidential Primary Debates" (2013). Communication Studies Faculty Publications. 9.

https://scholarworks.umt.edu/communications_pubs/9

This Article is brought to you for free and open access by the Communication Studies at ScholarWorks at University of Montana. It has been accepted for inclusion in Communication Studies Faculty Publications by an authorized administrator of ScholarWorks at University of Montana. For more information, please contact

scholarworks@mso.umt.edu. 


\title{
A FUNCTIONAL ANALYSIS OF 2012 U.S. PRESIDENTIAL PRIMARY DEBATES
}

\author{
Mark Glantz, William L. Benoit, and David Airne
}

This study examines the Republican primary debates from the 2012 U.S. presidential campaign. With a weak economy, numerous Republicans vied to challenge President Barack Obama who was completing his first term in office. Of course, former Massachusetts Governor Mitt Romney eventually seized the Republican nomination. This investigation employs content analysis and applies Functional Theory to the primary campaign debate messages. Acclaims were more common than attacks, which in turn occurred more frequently than defenses; and policy was discussed more often than character. Findings from the 2012 debates are compared with results from analysis of presidential primary debates in earlier campaigns.

Key Words: primary campaign, presidential primary debates, 2012 Republican primary candidates, Functional Theory

The president of the United States is the most powerful politician in the world. Therefore, the process of choosing a president is important both to the U.S. and the world. Since at least the 1870s, only candidates of the Democratic and Republican Parties have been elected president. This situation confers great importance on the primary race for a major-party nomination. In 2012, President Barack Obama's nomination as the Democratic candidate was not contested, so only the Republican Party had a primary campaign. (Of course, Obama used the primary period to campaign for himself and against the Republicans generally.) The economy was seen by many as relatively weak in 2011 , leading many Republican politicians to seek their party's nomination. As President Obama appeared vulnerable, many candidates vied for the chance to challenge the incumbent Democratic president. These candidates and their messages clearly deserve scholarly attention.

Since 1948, when Thomas E. Dewey and Harold Stassen participated in a debate on radio during the Oregon Republican primary campaign, presidential primary debates have been employed to help U.S. voters make a choice about who should be their party's nominee. In recent years, primary debates have been more numerous than debates in the general election campaign. In 2004 (the most recent campaign with a contested primary in only one political party), for instance, the campaign featured 21 primary, 3 presidential, and 1 vice presidential debates (Benoit et al., 2007). In 2008, 20 Democratic and 16 Republican primary debates were held (Benoit, Henson, \& Sudbrock, 2011). Various studies have found that voters can be influenced by presidential primary debates (Benoit, McKinney, \& Stephenson, 2002; Benoit \& Stephenson, 2004; Lanoue \& Schrott, 1989; Lemert, Elliot, Nestfold, \& Rarick, 1983; Pfau, 1984, 1987, 1988; Wall, Golden, \& James, 1988; Yawn, Ellsworth, Beatty, \& Kahn, 1998). Meta-analysis has also established that watching televised presidential primary debates can increase issue knowledge, affect perceptions of candidate character, and change vote choice (Benoit, Hansen, \& Verser, 2003); and these effects are even larger in primary than general debates, probably because voters have less knowledge, fewer candidate character perceptions, and weaker commitment to vote choice early in the campaign. Although the average viewership for primary debates is far less than that of general election debates,

Mark Glantz Department of Communication and Media Studies, St. Norbert College; William L. Benoit, School of Communication Studies, Ohio University; David Airne, Department of Communication Studies, University of Montana. A version of this paper was presented at the Midwest Political Science Association, April 2013. Correspondence concerning this article should be addressed to William L. Benoit, School of Communication Studies, Ohio University, Lasher Hall, Athens, Ohio, 45701. Email: benoitw@ohio.edu 
many voters do watch primary debates. For example, in 2008, 24 of the Democratic and Republican primary debates attracted a total of 90 million viewers (Kurtz, 2008; Memmott \& Carnia, 2007; Page, 2008). Balz (2012) argued that the Republican primary debates of 2012 made a difference: The debates "shaped the campaign and the fortunes of many of the candidates. Think Rick Perry" (para.1). There is no question that presidential primary debates merit scholarly attention.

\section{LITERAtUre Review}

Relatively few studies have used content analysis to examine U.S. presidential primary debates (for other kinds of research on this message form, see Berquist, 1960; Best \& Hubbard, 2000; Blankenship, Fine, \& Davis, 1983; Hellweg \& Phillips, 1981; Kane, 1987; Ray, 1961; Stelzner, 1971). A study of U.S. presidential primary debates from 1948-2000 employing Functional Theory offers several insights into the content of these messages (Benoit, Pier, et al., 2002). Acclaims were the most common function of these primary debates $(63 \%)$, followed by attacks $(32 \%)$ and defenses $(4 \%)$. When candidates did attack in primary debates, they were more likely to attack members of their own political party $(47 \%)$ than candidates in the opposing party $(30 \%)$ or to attack the status quo (criticisms that include members of both major political parties, $24 \%$ ). The candidates in primary debates discussed policy $(63 \%)$ more frequently than character $(37 \%)$. More of these policy utterances concerned general goals $(40 \%)$ or past deeds $(37 \%)$ than future plans $(24 \%)$. When candidates discussed character in primary debates, they discussed ideals $(45 \%)$ and personal qualities $(36 \%)$ more than leadership ability (19\%). Benoit et al. (2007) reported similar patterns in the 2004 Democratic primary debates where candidates employed acclaims (63\%) more than attacks $(32 \%)$ or defenses $(4 \%)$. About three fourths of their statements concerned policy (and the remainder character). One contrasting finding was that these Democratic candidates were more likely to direct attacks toward Republican President Bush (65\%) than to one another $(21 \%)$ or the establishment generally (15\%). Also, Benoit et al. (2011) analyzed presidential primary debates in the 2008 election. Acclaims were again the most common function $(68 \%)$, followed by attacks $(26 \%)$ and defenses $(6 \%)$. These candidates discussed policy more than character ( $70 \%$ to $30 \%)$. We extend this line of analysis in the current study, employing Functional Theory to analyze primary debates from Republicans in the 2012 U.S. presidential campaign.

\section{Functional Theory}

The Functional Theory of Political Campaign Discourse was developed by Benoit and his associates through a series of studies (see, e.g., Benoit, 1999, 2007; Benoit, Blaney, \& Pier, 1998; Benoit \& Brazeal, 2002; Benoit \& Harthcock, 1999; Benoit, Pier et al., 2002, Benoit, Stein et al., 2007). Functional Theory posits that citizens vote for the candidate who appears preferable on the criteria that are considered most important to each voter (Benoit, 2007). Candidates can demonstrate their desirability in three ways. First, the candidate can engage in acclaiming or self-praise. The greater the benefits or advantages of one candidate, the more likely that person will appear preferable to voters, compared with opponents. Second, candidates can attack or criticize opponents; and as voters become aware of more costs or disadvantages of opponents, those competitors should appear less desirable to voters (of course, it is possible that the source of these attacks can experience a backlash from voters who dislike mudslinging). Finally, candidates who have been the target of attack can defend 
against (refute) those attacks. The fewer and smaller the costs or disadvantages, the more likely that a candidate will appear preferable to opponents. These three options can be seen as roughly similar to cost-benefit analysis, providing information that can help persuade the voter to prefer one candidate over others (yet we do not claim that voters systematically quantify the impact of acclaims, attacks, or defenses or perform mathematical calculations to decide their vote choice; acclaims may increase one's benefits, attacks are capable of increasing an opponent's costs, and defenses may reduce one's costs). For example, research on German presidential debates has confirmed that viewers react differently to acclaims and attacks (Reinemann \& Maurer, 2005). However, it is important to keep in mind that all voters do not react in the same way to a given utterance. For example, Jarman (2005) found that those who watched the second general election presidential debate in 2004 evaluated the comments from the candidate representing their own party more favorably than viewers who affiliate with the opposing party.

The three functions (acclaims, attacks, and defenses) can be employed on two topics, policy (issues) or character (personality). Policy utterances address governmental action or problems that are amenable to governmental action (past deeds, future plans, general goals). Character comments are about the candidates as individuals (personality, leadership experience, and values). Of course, the relative importance of these two general topics of discourse can vary from one voter to another. Functional theory also subdivides the two topics into three forms of policy and three forms of character. The Appendix provides illustrations of acclaims and attacks on the three forms of policy and three forms of character.

Functional Theory (Benoit, 2007) expects that acclaims will occur more often than attacks. Acclaims have no drawbacks, but as many voters report that they dislike mudslinging (Merritt, 1984; Stewart, 1975), there is some incentive for candidates to moderate their attacks. Defenses are expected to be rare for three reasons: Most attacks occur where a candidate is weak, so responding to an attack will usually take the candidate off-message; one must identify an attack to refute it and that identification may inform or remind voters of a potential weakness; and attacks may create the undesirable impression that the candidate is reactive rather than proactive. Based on previous research (Benoit, 2007; Benoit et al., 2011) and the assumptions of Functional Theory, we posit the following hypothesis:

H1: U.S. presidential primary debate utterances in the 2012 election will use more acclaims than attacks and more attacks than defenses.

Functional Theory also assumes that the target of attack matters in a presidential primary. Does Romney, for example, attack Obama or Gingrich? To address this concern, we pose this research question:

RQ1: What are the targets of attack in the 2012 Republican presidential primary debates?

Research on previous presidential primary debates has found that policy is more common than character (Benoit, 2007). Public opinion polls for presidential elections in the United States reveal that most voters say that policy is a more important influence on their vote than character (Benoit, 2003). Because candidates have incentive to adapt to voter desires, Functional Theory predicts that policy will receive a heavier emphasis than character:

H2: U.S. presidential primary debate utterances in the 2012 election will discuss policy more than character.

This prediction is also consistent with past research on primary debates (Benoit, 2007; Benoit et al., 2011). 
We also investigate the distribution of the three forms of policy and three forms of character in these debates with the following questions:

RQ2: What is the relative emphasis on the three forms of policy in the 2012 U.S. presidential primary debates?

RQ3: What is the relative emphasis on the three forms of character in the 2012 U.S. presidential primary debates?

Finally, Functional Theory predicts that candidates will be more likely to use general goals and ideals as the basis for acclaims rather than attacks (Benoit, 2007; Benoit et al., 2011). Some ends are generally not susceptible to attack. For example, how does one oppose a goal such as creating jobs or making America secure? Our last hypotheses predict that:

H3: General goals will be employed more frequently as the basis for acclaims than for attacks in the 2012 U.S. presidential primary debates.

H4: Ideals will be employed more frequently as the basis for acclaims than for attacks in the 2012 U.S. presidential primary debates.

These hypotheses and research questions guide our analysis of primary debates from the 2012 Republican presidential campaign.

\section{METHOD}

Sample

The Republican presidential primary debates started more than a year before the Republican nomination was secured, with the first primary clash occurring in June of 2011. This study reports content analysis of the 19 Republican presidential primary debates from the 2012 campaign for which full transcripts could be located on the internet at the time of the study. The candidates who participated in at least one of these debates were Michele Bachmann, Herman Cain, Newt Gingrich, Jon Huntsman, Gary Johnson, Ron Paul, Tim Pawlenty, Rick Perry, Mitt Romney (who won the Republican nomination), and Rick Santorum. Table 1 lists the debates included in this sample and who participated in each one.

\section{Coding Procedures}

The content analysis employed here, following previous research using the Functional approach, consisted of four steps. First, the texts of debates were unitized into themes, or utterances that address a coherent idea (only candidate remarks were coded, although questions were part of the context unit used to interpret the candidates' utterances). A theme is the smallest unit of discourse that is capable of expressing a complete idea. This is consistent with Berelson (1952), who indicated that a theme is "an assertion about a subject" (p. 18). Similarly, Holsti (1969) defined a theme as "a single assertion about some subject" (p. 116). Themes vary in length from a short phrase to several sentences: The textual excerpt must focus on a single idea (a single function and a single topic) to qualify as a theme. For example, in the Orlando debate of September 22, 2011, Rick Perry declared that "What we have done in the state of Texas over the course of the last decade is to lower the tax burden on the small businessmen and women, have a regulatory climate that is fair and predictable, and sweeping tort reform." This statement would be unitized into three themes (all acclaims, all on past deeds) on tax reduction, regulatory reform, and tort reform. 
TABLE 1

Participation in 2012 Republican Presidential Primary Debates

\begin{tabular}{|c|c|c|c|c|c|c|c|c|c|c|}
\hline & Bachmann & Cain & Gingrich & Huntsman & Johnson & Paul & Pawlenty & Perry & Romney & y Santorum \\
\hline $\begin{array}{l}\text { Manchester NH } \\
(6 / 13)\end{array}$ & $\mathrm{X}$ & $X$ & $\mathrm{X}$ & & & $\mathrm{X}$ & $\mathrm{X}$ & & $\mathrm{x}$ & $\mathrm{X}$ \\
\hline $\begin{array}{l}\text { Ames LA (8/11) } \\
\text { Simi Valley CA } \\
(9 / 7)\end{array}$ & $\underset{\mathrm{X}}{\mathrm{X}}$ & $\begin{array}{l}\mathrm{X} \\
\mathrm{X}\end{array}$ & $\begin{array}{l}\mathrm{X} \\
\mathrm{X}\end{array}$ & $\begin{array}{l}\mathrm{X} \\
\mathrm{X}\end{array}$ & & $\begin{array}{l}\mathrm{X} \\
\mathrm{X}\end{array}$ & & $\begin{array}{l}\mathrm{X} \\
\mathrm{X}\end{array}$ & $\begin{array}{l}\mathrm{X} \\
\mathrm{X}\end{array}$ & $\begin{array}{l}\mathrm{X} \\
\mathrm{X}\end{array}$ \\
\hline $\begin{array}{c}\text { Tampa FL } \\
(9 / 12)\end{array}$ & $\mathrm{X}$ & $\mathrm{x}$ & $\mathrm{X}$ & $\mathrm{x}$ & & $\mathrm{X}$ & & $\mathrm{X}$ & $\mathrm{X}$ & $\mathrm{X}$ \\
\hline $\begin{array}{c}\text { Orlando FL } \\
(9 / 22)\end{array}$ & $\mathrm{X}$ & $\mathrm{X}$ & $\mathrm{X}$ & $\mathrm{X}$ & $\mathrm{X}$ & $\mathrm{X}$ & & $\mathrm{X}$ & $\mathrm{X}$ & $\mathrm{X}$ \\
\hline $\begin{array}{l}\text { Hanover NH } \\
(10 / 12)\end{array}$ & $\mathrm{X}$ & $\mathrm{X}$ & $\mathrm{X}$ & $\mathrm{X}$ & & $X$ & & $\mathrm{X}$ & $\mathrm{X}$ & $\mathrm{X}$ \\
\hline $\begin{array}{l}\text { Las Vegas NV } \\
(10 / 18)\end{array}$ & $\mathrm{x}$ & $\mathrm{X}$ & $\mathrm{X}$ & & & $\mathrm{X}$ & & $\mathrm{X}$ & $\mathrm{X}$ & $\mathrm{x}$ \\
\hline $\begin{array}{l}\text { Rochester MI } \\
\text { (11/9) }\end{array}$ & $\mathrm{X}$ & $\mathrm{X}$ & $\mathrm{X}$ & $\mathrm{X}$ & & $\mathrm{X}$ & & $\mathrm{X}$ & $X$ & $X$ \\
\hline $\begin{array}{l}\text { Spartanburg SC } \\
(11 / 12)\end{array}$ & $X$ & $\mathrm{X}$ & $X$ & $\mathrm{X}$ & & $\mathrm{X}$ & & $\mathrm{X}$ & $\mathrm{X}$ & $\mathrm{X}$ \\
\hline $\begin{array}{l}\text { Washington DC } \\
(11 / 22)\end{array}$ & $\mathrm{X}$ & $\mathrm{X}$ & $\mathrm{X}$ & $\mathrm{X}$ & & $\mathrm{X}$ & & $\mathrm{X}$ & $\mathrm{X}$ & $\mathrm{X}$ \\
\hline $\begin{array}{l}\text { Des Moines IA } \\
\quad(12 / 10)\end{array}$ & $\mathrm{X}$ & & $\mathrm{X}$ & & & $\mathrm{X}$ & & $\mathrm{X}$ & $X$ & $X$ \\
\hline $\begin{array}{l}\text { Sioux City IA } \\
(12 / 15)\end{array}$ & $\mathrm{X}$ & & $\mathrm{X}$ & $\mathrm{X}$ & & $\mathrm{X}$ & & $\mathrm{X}$ & $\mathrm{X}$ & $\mathrm{X}$ \\
\hline $\begin{array}{l}\text { Manchester NH } \\
(1 / 7)\end{array}$ & $\mathrm{X}$ & & $\mathrm{X}$ & $\mathrm{X}$ & & X & & $\mathrm{X}$ & $\mathrm{X}$ & $\mathrm{X}$ \\
\hline $\begin{array}{c}\text { Concord NH } \\
(1 / 8)\end{array}$ & & & $\mathrm{X}$ & $\mathrm{X}$ & & $\mathrm{X}$ & & $\mathrm{X}$ & $\mathrm{X}$ & $\mathrm{X}$ \\
\hline $\begin{array}{l}\text { Myrtle Beach SC } \\
(1 / 16)\end{array}$ & & & $X$ & & & $X$ & & $\mathrm{X}$ & $X$ & $\mathrm{X}$ \\
\hline $\begin{array}{c}\text { Charleston SC } \\
(1 / 19)\end{array}$ & & & $\mathrm{X}$ & & & $\mathrm{X}$ & & & $\mathrm{X}$ & $\mathrm{X}$ \\
\hline$\underset{(1 / 23)}{\text { Tampa FL }}$ & & & $\mathrm{X}$ & & & $\mathrm{X}$ & & & $\mathrm{X}$ & $\mathrm{X}$ \\
\hline $\begin{array}{l}\text { Jacksonville FL } \\
(1 / 26)\end{array}$ & & & $\mathrm{X}$ & & & $\mathrm{x}$ & & & $\mathrm{X}$ & $\mathrm{X}$ \\
\hline $\begin{array}{c}\text { Mesa AZ } \\
(2 / 22)\end{array}$ & & & $X$ & & & $\mathrm{X}$ & & & $\mathrm{X}$ & $\mathrm{X}$ \\
\hline Total & 13 & 10 & 19 & 11 & 1 & 19 & 1 & 14 & 19 & 19 \\
\hline
\end{tabular}

Second, each theme's function was classified using the following rules:

- Acclaims portray the candidate speaking favorably.

- Attacks portray opponents unfavorably.

- Defenses respond to a prior attack on the candidate who is speaking.

Almost all utterances in the texts of the debates in our sample served one of these functions; the very few other (non-functional) utterances that occurred were not analyzed.

Third, the topic of each theme was classified according to these rules:

- Policy remarks concern governmental action and problems amenable to such action.

- Character remarks address properties, abilities, or attributes of the candidates.

Because defenses occur infrequently they were not coded by topic (policy or character). Finally, policy themes were coded into one of the three forms of policy while character themes were categorized as one of the three forms of character. The Appendix provides 
TABLE 2.

Functions of 2012 Presidentlal Primary Debates

\begin{tabular}{lccc}
\hline & Acclaims & Attacks & Defenses \\
\hline 2012 & $3527(67 \%)$ & $1565(30 \%)$ & $141(3 \%)$ \\
$1948-2008$ & $26853(65 \%)$ & $12603(30 \%)$ & $2058(5 \%)$ \\
\hline \hline
\end{tabular}

Note. 1948-2008 data from Benoit (2007) and Benoit, Henson, \& Sudbrock (2011).

examples of acclaims and attacks on the three forms of policy and of character, taken from a 2012 presidential primary debate.

We employed Cohen's (1960) $\kappa$ for calculating inter-coder reliability because this statistic controls for agreement by chance. Reliability was calculated on about $10 \%$ of the texts. The ks were .94 and .91 for functions (three coders), .89 and .86 for topics, .86 and .91 for forms of policy, .83 and .89 for forms of character, and .96 for target of attack (two coders). Landis and Koch (1977) indicate that these levels of agreement are acceptable: $\kappa s$ of .81 and above reflect "almost perfect" agreement (p. 165).

\section{Results}

This section presents the results of the content analysis of texts of the 2012 presidential primary debates. Our first hypothesis concerns the functions of the Republican presidential primary debates. As Table 2 indicates, these debates were mostly positive: $67 \%$ acclaims, $30 \%$ attacks, and 3\% defenses (a goodness of fit test reveals this distribution is significant: $\chi^{2}$ $[d f=2]=3314.01, p<.0001$ ). For example, Michele Bachmann explained that, "I think you earned every dollar. You should get to keep every dollar that you earn. That's your money; that's not the government's money" (Orlando, 9/22/11). Particularly given a conservative Republican audience for the debate, this statement clearly illustrates an acclaim. Mitt Romney declared that "President Obama had done everything wrong" on small businesses (Orlando, 9/22/11). This is without question a criticism of the incumbent president (an attack). Rick Perry was attacked for being soft on immigration. He responded that "there is nobody on this stage who has spent more time working on border security than I have" (Orlando, 9/22/11), an example of a defense. Although the 2012 Republican primary debates have only slightly more acclaims and fewer defenses than debates from earlier campaigns, 1948-2008, these differences are still statistically significant because of the large sample size $\left(\chi^{2}[d f=2]=56.17, p<.0001, V=.03\right)$.

The first research question investigated the target of attack in these debates. Democratic President Barack Obama was the target of most attacks at $43 \%$ (see Table 3). Other Republicans were the focus of $37 \%$ of the attacks with $20 \%$ directed at the status quo (laments about problems which did not identify either party for blame). Among the Republican candidates, Romney (87) and Gingrich (86) received the most attacks. Pawlenty, Johnson, Cain, and Bachmann all received fewer than 10 attacks in these debates.

Hypothesis two predicted that these candidates would discuss policy more than character. This expectation was confirmed with $67 \%$ policy and $33 \%$ character discussion (a goodness of fit test indicates that this distribution is significant: $\chi^{2}[d f=1]=564.22, p<.0001$ ). Herman Cain discussed policy (foreign policy) when he asserted that "We will stand solidly behind Israel" (Orlando, 9/22/11). Jon Huntsman touted his leadership ability, an element of character, when he noted that he was "the only one on stage with any hands-on foreign 


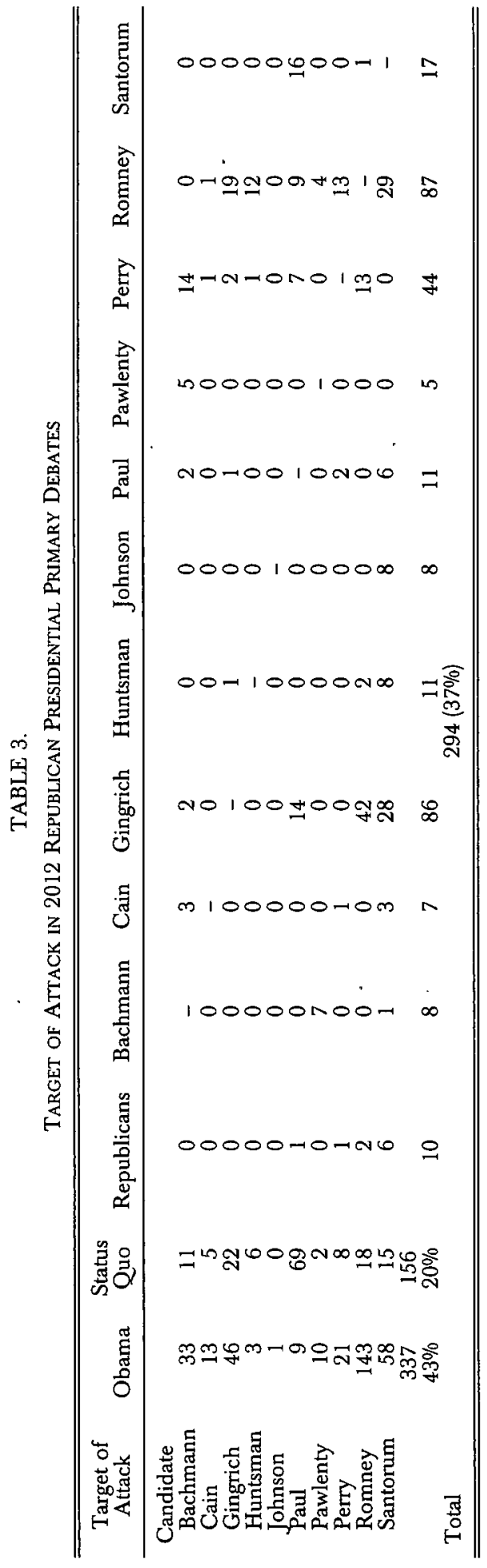


TABLE 4.

Topics of 2012 Presidential Primary Debates

\begin{tabular}{crr}
\hline \hline & \multicolumn{1}{c}{ Policy } & Character \\
\hline 2012 & $3394(67 \%)$ & $1698(33 \%)$ \\
$1948-2008$ & $27612(70 \%)$ & $11749(30 \%)$ \\
\hline \hline
\end{tabular}

Note. 1948-2008 data from Benoit (2007) and Benoit, Henson, \& Sudbrock (2011).

policy experience, having ... lived overseas four different times" (Orlando, 9/22/11). These debates discussed policy slightly less, and character a bit more, than previous debates, yet this difference is significant because of the sample size $\left(\chi^{2}[d f=1]=26.14, p<.0001, \varphi=\right.$ .02). These data are presented in Table 4.

Our second research question asked about the relative emphasis of the three forms of policy. Candidates used general goals $(47 \%)$ and past deeds $(45 \%)$ at about the same rate, both more often than future plans $(8 \%)$. These differences are significant (goodness of fit test: $\left.\chi^{2}[d f=2]=993.52 . p<.0001\right)$. The forms of policy here occurred in the same order as in previous debates (see Table 5), although the emphases did vary $\left(\chi^{2}[d f=2]=174.68 . p<\right.$ $.0001, V=.08)$. In 2012, there was greater discussion of past deeds and less use of future plans and general goals.

The third research question concerned the three forms of character in the 2012 Republican primary debates. Personal qualities were the most common form of character $(55 \%)$, followed by leadership ability $(25 \%)$ and ideals $(20 \%)$. This distribution was different from what would be expected by chance $\left(\chi^{2}[d f=2]=374.55 . p<.0001\right)$. In 2012, personal qualities and leadership ability were more common than in previous debates, whereas ideals were less common $\left(\chi^{2}[d f=2]=73.85 . p<.0001, V=.07\right)$. See Table 6 for these data.

The last two hypotheses concerned the use of one form of policy (general goals) and one form of character (ideals) as the basis for acclaims and attacks. Both hypotheses were confirmed. General goals were used more frequently to acclaim than attack $(90 \%, 10 \%$; a goodness of fit test confirms that this distribution is significant: $\chi^{2}[d f=1]=1029.5, p<$ $.0001)$. These data are found in Table 5. Ideals were more often the basis for acclaims than attacks $\left(95 \%, 5 \%\right.$; a goodness of fit test indicates that this distribution is significant: $\chi^{2}[d f=$ $1]=218.92, p<.0001)$. These data are presented in Table 6 .

\section{Discussion}

Acclaims were more common than attacks and defenses were the least common function in the 2012 Republican presidential primary debates. As Functional Theory (Benoit, 2007)

TABLE 5 .

Forms of Policy in 2012 Presidential Primary Debates

\begin{tabular}{|c|c|c|c|c|c|c|}
\hline & \multicolumn{2}{|c|}{ Past Deeds } & \multicolumn{2}{|c|}{ Future Plans } & \multicolumn{2}{|c|}{ General Goals } \\
\hline & Acclaims & Attacks & Acclaims & $\overline{\text { Attacks }}$ & Acclaims & $\overline{\text { Attacks }}$ \\
\hline 2012 & \multicolumn{2}{|c|}{$537_{1544(45 \%)} 1007$} & 252 & 14 & \multicolumn{2}{|c|}{$1431_{1584(47 \%)}^{153}$} \\
\hline $1948-2008$ & \multicolumn{2}{|c|}{$9530(35 \%)$} & \multicolumn{2}{|c|}{$3331(12 \%)$} & \multicolumn{2}{|c|}{$14751(53 \%)$} \\
\hline
\end{tabular}

Note. 1948-2008 data from Benoit et al., 1998, 2002, 2007 and Benoit, Henson, \& Sudbrock (2011). 
TABLE 6.

Forms of Character in 2012 Presidential Primary Debates

\begin{tabular}{|c|c|c|c|c|c|c|}
\hline & \multicolumn{2}{|c|}{ Personal Qualities } & \multicolumn{2}{|c|}{ Leadership Ability } & \multicolumn{2}{|c|}{ Ideals } \\
\hline & $\overline{\text { Acclaims }}$ & $\overline{\text { Attacks }}$ & Acclaims & $\overline{\text { Attacks }}$ & Acclaims & $\overline{\text { Attacks }}$ \\
\hline 2012 & \multicolumn{2}{|c|}{$682 \quad 256$} & \multicolumn{2}{|c|}{$323_{427(25 \%)} 1$} & \multicolumn{2}{|c|}{302 333 (20\%) } \\
\hline $1948-2008$ & \multicolumn{2}{|c|}{$\begin{array}{c}3375 \\
5937(50 \%)\end{array} 2562$} & \multicolumn{2}{|c|}{$\begin{array}{c}1764 \\
2417(20 \%)\end{array} 653$} & \multicolumn{2}{|c|}{$\begin{array}{c}3068 \\
3480(29 \%)\end{array}$} \\
\hline
\end{tabular}

Note. 1948-2008 data from Benoit et al., 1998, 2002, 2007 and Benoit, Henson, \& Sudbrock (2011).

explains, acclaims have no drawbacks, attacks can produce some backlash from voters who dislike mudslinging, and defenses have multiple drawbacks (they may inform or remind voters of a potential weakness, they may create the impression that the candidate is reactive rather than proactive, and they often take a candidate off message). This relationship has held true in previous primary debates and continues in these 2012 debates. If voters believe political campaigns are mostly negative, that impression may have been fostered by news coverage which reports on attacks much more often than they occur in presidential primary debates (Benoit, Hansen, \& Stein, 2004).

The target of most attacks was the Democratic incumbent, President Barack Obama. As mentioned earlier, the economy was seen as weak and the Republican contenders fought to contest the general election against Obama's perceived poor performance. Among the Republican candidates, Mitt Romney and Newt Gingrich received the most attacks. This is due to a confluence of two factors: Romney and Gingrich were among the four candidates who participated in all 19 primary debates we analyzed, so there were more opportunities to attack these two than other candidates, such as Pawlenty or Johnson. Also, Romney and Gingrich were among the leaders in the polls, so other candidates had more to gain from criticizing them than, say, Michelle Bachmann. Of course, some attacks are motivated by genuine differences or dislike, but these two factors play an important role in target of attack (see Benoit et al., 2002).

The 2012 Republican candidates discussed policy more frequently than character in their primary debate statements. This finding is consistent with past research and also with the fact that in the last 30 years more U.S. citizens have reported that policy is a more important determinant for their vote for president than identify candidate character (Benoit, 2003). Although time restrictions do limit how much depth candidates can offer as they discuss policy in a campaign debate-and it is possible that some candidates may avoid specificity because of concerns that too many policy details may provoke more attacks-the candidates in these debates clearly did not spend most of their time dwelling on candidate personality or character. The emphasis on policy over character is consistent with primary debates from earlier campaigns. Questions asked of the candidates in debates obviously exert some influence on the candidate statements (e.g., if asked repeatedly about character, the candidates have little choice but to devote time to that topic), but the participants in these encounters at times discuss topics not raised in the questions.

These data on the Republican 2012 primary debates confirmed that certain types of utterances-general goals and ideals-lend themselves more easily to one function (acclaims). Many goals and values, such as national security, employment, a strong economy, freedom, or equal opportunities, are much easier to acclaim (agree with) than to attack (reject). 


\section{Conclusion}

These findings add to our understanding of U.S. presidential primary campaigns and debates. In 2012, only the Republican nomination was contested and campaign debates were an important medium for this contest. As in earlier elections, the candidates relied most heavily on acclaims, then attacks, and thirdly on defenses. Attacks targeted the incumbent president from the other political party, followed by Mitt Romney and Newt Gingrich. These debates stressed policy more than character, and general goals and past deeds were used more than future plans. When discussing character, candidates addressed personal qualities most, followed by leadership ability and then ideals. When they discussed both general goals and ideals, candidates were prone to acclaim more than to attack. This study adds to our overall understanding of the nature of presidential primary debates.

\section{REFERENCES}

Balz, D. (2012, July 29). 8 Questions. The Washington Post. Retrieved from http J/www.washingtonpost

Benoit, W. L. (1999). Seeing spots: A functional analysis of presidential television advertisements, 1952-1996. Westport, CT: Praeger.

Benoit, W. L. (2003). Topic of presidential campaign discourse and election outcome. Western Journal of Communication, 67, 97-112.

Benoit, W. L. (2007). Communication in political campaigns. New York, NY: Peter Lang

Benoit, W. L., Blaney, J. R., \& Pier, P. M. (1998). Campaign '96: A functional analysis of acclaiming, attacking, and defending. Westport, CT: Praeger.

Benoit, W. L., \& Brazeal, L. M. (2002). A functional analysis of the 1988 Bush-Dukakis presidential debates. Argumentation and Advocacy, 38, 219-233.

Benoit, W. L., Hansen, G. J., \& Stein, K. A. (2004). News coverage of presidential primary debates. Argumentation and Advocacy, 40, 246-258.

Benoit, W. L., Hansen, G. J., \& Verser, R. M. (2003). A meta-analysis of the effects of viewing U.S. presidential debates. Communication Monographs, 70, 335-350.

Benoit, W. L., \& Harthcock, A. (1999). Functions of the great debates: Acclaims, attacks, and defenses in the 1960 presidential debates. Communication Monographs, 66, 341-357.

Benoit, W. L., Henson, J. R., \& Sudbrock, L. A. (2011!. A functional analysis of 2008 American presidential primary debates. Argumentation: Inquiry and Advocacy, 48, 97-110.

Benoit, W. L., McKinney, M. S., \& Stephenson, M. T. (2002). Effects of watching campaign 2000 presidential primary debates. Journal of Communication, 52, 316-331.

Benoit, W. L., Pier, P. M., Brazeal, L. M., McHale, J. P., Klyukovksi, A., \& Airne, D. (2002). The primary decision: A functional analysis of debates in presidential primaries. Westport, CT: Praeger.

Benoit, W. L., Stein, K. A., McHale, J. P., Chattopadhyay, S., Verser, R., \& Price, S. (2007). Bush versus Kerry: $A$ functional analysis of campaign 2004. New York, NY: Peter Lang.

Benoit, W. L., \& Stephenson, M. T. (2004). Effects of watching a presidential primary debate. Contemporary Argumentation and Debate, 25, 1-25.

Berelson, B. (1952). Content analysis for the social sciences and humanities. Reading, MA: Addison-Wesley.

Berquist, G. F. (1960). The Kennedy-Humphrey debate. Today's Speech, 8(2-3), 31 .

Best, S. J., \& Hubbard, C. (2000). The role of televised debates in the presidential nominating process. In W. G. Mayer (Ed.), In pursuit of the White House 2000: How we choose our presidential nominees (pp. 255-284). New York, NY: Chatham House.

Blankenship, J., Fine, M. G., \& Davis, L. K. (1983). The 1980 Republican primary debates: The transformation of actor to scene. Quarterly Journal of Speech, 64, 25-36.

Cohen, J. (1960). A coefficient of agreement for nominal scales. Educational and Psychological Measurement, 20, 37-46.

Hellweg, S. A., \& Phillips, S. L. (1981). A verbal and visual analysis of the 1980 Houston Republican primary debate. Southern Speech Communication Journal, 47, 23-38.

Holsti, O. (1969). Content analysis in communication research. New York, NY: Free Press.

Jarman, J. W. (2005). Political affiliation and presidential debates: A real-time analysis of the effect of the arguments used in the presidential debates. American Behavioral Scientist, 49, 229-242.

Kane, T. (1987). The Dewey-Stassen primary debate of 1948: An examination of format for presidential debates. In J. Wenzel (Ed.), Argument and critical practices (pp. 249-253). Annandale, VA: Speech Communication Association. Kurtz, H. (2008, April 18). Performance by ABC's moderators is a matter of debate. The Washington Post, p. C1.

Landis, J. R., \& Koch, G. G. (1977). The measurement of observer agreement for categorical data. Biometrics, 33, $159-174$.

Lanoue, D. J., \& Schrott, P. R. (1989). Voter's reactiors to televised presidential debates: Measurement of the source and magnitude of opinion change. Political Psychology, 10, 275-285.

Lemert, J. B., Elliot, W. R., Nestfold, K. J., \& Rarick, G. R. (1983). Effects of viewing a presidential primary debate: An experiment. Communication Research, 10, 155-173. 
Memmott, M., \& Carnia, C. (2007, November 28). GOP presidential candidates to go another round. USA Today, p. $5 \mathrm{~A}$.

Merritt, S. (1984). Negative political advertising: Some empirical findings. Journal of Advertising, 13, 27-38.

Page, S. (2008, April 14). Democrat debates: One year later it's Clinton vs. Obama. USA Today, p. 6A.

Pfau, M. (1984). A comparative assessment of intra-party political debate formats. Political Communication Review, 8 , $1-23$.

Pfau, M. (1987). The influence of intraparty debates on candidate preference. Communication Research, 74, 687-697.

Pfau, M. (1988). Intra-party political debates and issue learning. Journal of Applied Communication Research, 16, $99-112$.

Ray, R. F. (1961). Thomas E. Dewey: The great Oregon debate of 1948. In R. Reid (Ed.), American public address: Studies in honor of Albert Craig Baird (pp. 245-270). Columbia: University of Missouri Press.

Reinemann, C., \& Maurer, M. (2005). Unifying or polarizing? Short-term effects and postdebate consequences of different rhetorical strategies in televised debates. Journal of Communication, 55, 775-794.

Stelzner, H. G. (1971). Humphrey and Kennedy court West Virginia, May 3, 1960. Southern Speech Journal, 37, 21-33.

Stewart, C. J. (1975). Voter perception of mud-slinging in political communication. Central States Speech Journal, 26, $279-286$.

Wall, V., Golden, J. L., \& James, H. (1988). Perceptions of the 1984 presidential debates and a select 1988 presidential primary debate. Presidential Studies Quarterly, 78, 541-563.

Yawn, M., Ellsworth, K., Beatty, B., \& Kahn, K. F. (1998). How a presidential primary debate changed attitudes of audience members. Political Behavior, 20, 155-181.

APPENDLX:

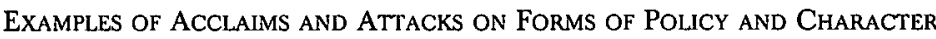

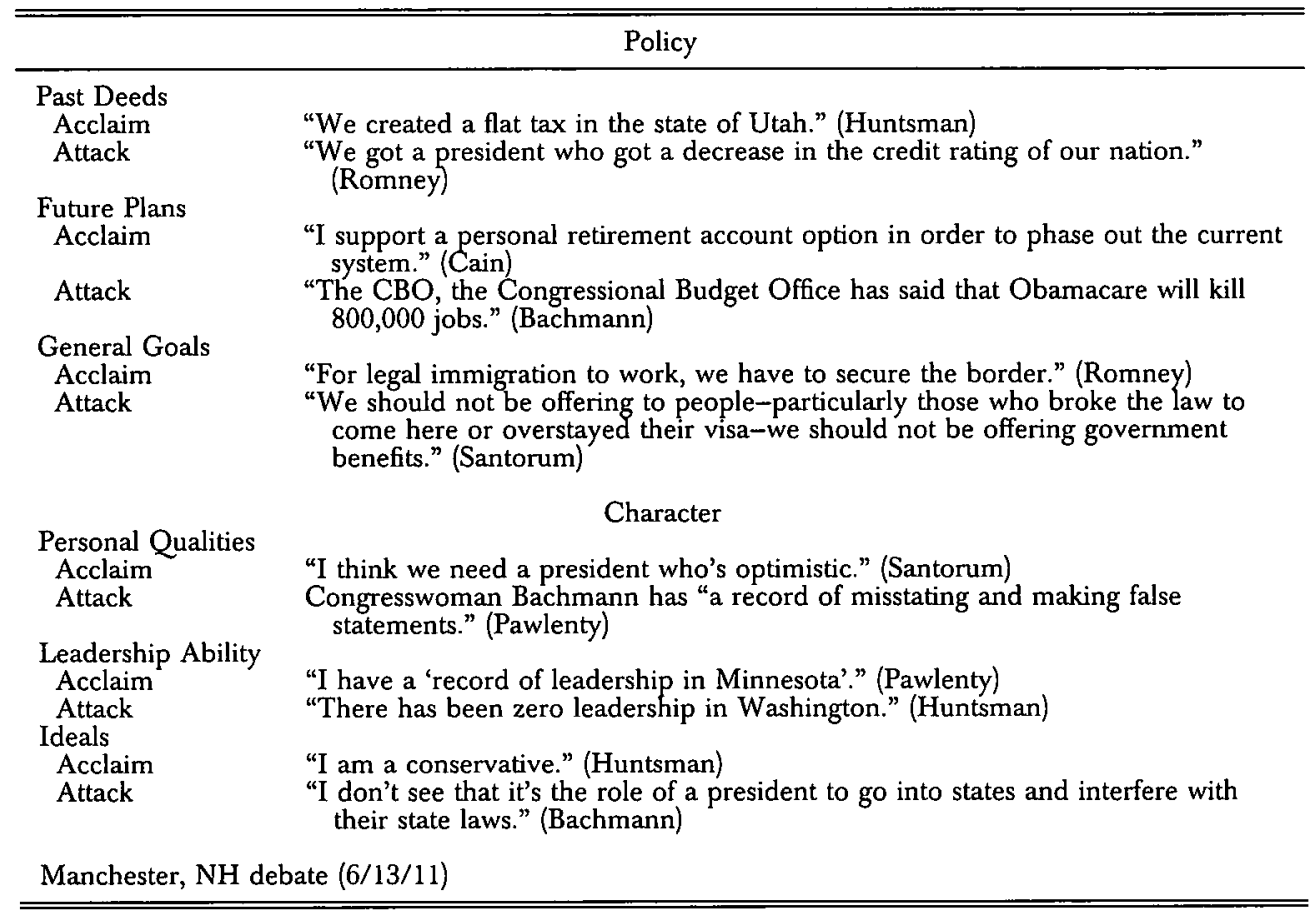


Copyright of Argumentation \& Advocacy is the property of American Forensic Association and its content may not be copied or emailed to multiple sites or posted to a listserv without the copyright holder's express written permission. However, users may print, download, or email articles for individual use. 